Western North American Naturalist 69(2), ㄷ 2009, pp. 155-164

\title{
PHYTOGEOGRAPHY AND FLORISTICS OF PINYON-JUNIPER WOODLANDS IN NORTHERN ARIZONA
}

\author{
Kyle Christie ${ }^{1}$
}

\begin{abstract}
This study assesses the floristic diversity and affinities of pinyon-juniper (PJ) woodlands in northern Arizona at 2 different scales: regionally within the context of North American floristic patterns and locally within the 2500m elevation gradient of the San Francisco Volcanic Field (SFVF). An analysis based upon 245 North American floras indicates that the PJ woodlands of the SFVF share strong affinities with the adjacent Colorado Plateau and Apachian floristic elements but also show high floristic similarity to the Great Plains. Data suggest that mid-elevation woodlands of the Colorado Plateau share floristic affinities with the Great Plains that are as strong as or stronger than those shared with the Great Basin. A geostatisical analysis provides a spatially explicit depiction of these findings. A comparison of species occurrences between 6 adjacent biotic communities in northern Arizona reveals that the PJ woodlands host the most distinctive flora among local life zones. Despite what their simple woodland structure may suggest, PJ woodlands of the SFVF host a moderately species-rich flora. This study suggests that the floras of PJ woodlands vary in significant and important ways across the range of PJ woodlands in western North America.
\end{abstract}

Key words: biogeography, phytogeography, floristics, pinyon-juniper woodlands, San Francisco Volcanic Field, Colorado Plateau.

\section{Regional Floristic Affinities}

Phytogeography, or the biogeography of plants, examines the spatial distributions and relationships of plant species (Good 1974). Individual plants inhabit specific geographic areas based upon a myriad of factors including climate, topography, physiology, and evolutionary and migrational history (Westoby and Wright 2006). Plant geographers have long struggled to classify regions of the world by cohesive and characteristic floristic elements (Takhtajan 1986). While it is often impossible to elucidate how or why the synergy of climate, topography, history, and geography favors a specific assemblage of plants in a specific region, biogeographers nevertheless strive to identify these unified regions. Plant geographers commonly delimit floristic elements based on geographically restricted and endemic taxa (Takhtajan 1986) or based on shared taxa (Stott 1981). McLaughlin (1986, 1989, 1994) has used overlap in the ranges of many species to extensively define areas of floristic similarity in the southwestern United States.

The San Francisco Volcanic Field (SFVF) of northern Arizona lies near the junction of the
Colorado Plateau and Apachian floristic zones (Fig. 1) and hosts many characteristic southwestern taxa (McLaughlin 1986, 1992), such as Eriogonum Michx., Astragalus L., Cryptantha Lehm. ex G. Don, Penstemon Schmidel, Phacelia Juss., and Muhlenbergia Schreb. Due to its unique geographic location, the SFVF also harbors many species growing near the limits of their ranges. Many northern species with affinities to the Great Basin, Rocky Mountains, and northern Great Plains (e.g., Artemisia frigida Willd., Ephedra viridis Coville, Eriogonum corymbosum Benth., Hesperostipa comata [Trin. \& Rupr.] Barkworth, and Hymenoxys richardsonii [Hook.] Cockerell) reach the southern extent of their distributions on the southern Colorado Plateau. Other more southern species with Madrean, Chihuahuan, and Sonoran affinities (e.g., Bouteloua aristidoides [Kunth] Griseb., Juglans major [Torr.] A. Heller, Juniperus deppeana Steud., Menodora scabra A. Gray, Muhlenbergia pauciflora Buckley, and Muhlenbergia porteri Scribn. ex Beal) reach the northern extent of their distributions near the Mogollon Rim at the southern terminus of the Colorado Plateau. A number of eastern and Great Plains species (e.g.,

${ }^{1}$ Deaver Herbarium, Department of Biological Sciences, Northern Arizona University, Flagstaff, AZ 86011-5640. E-mail: kylechristiel@hotmail.com 


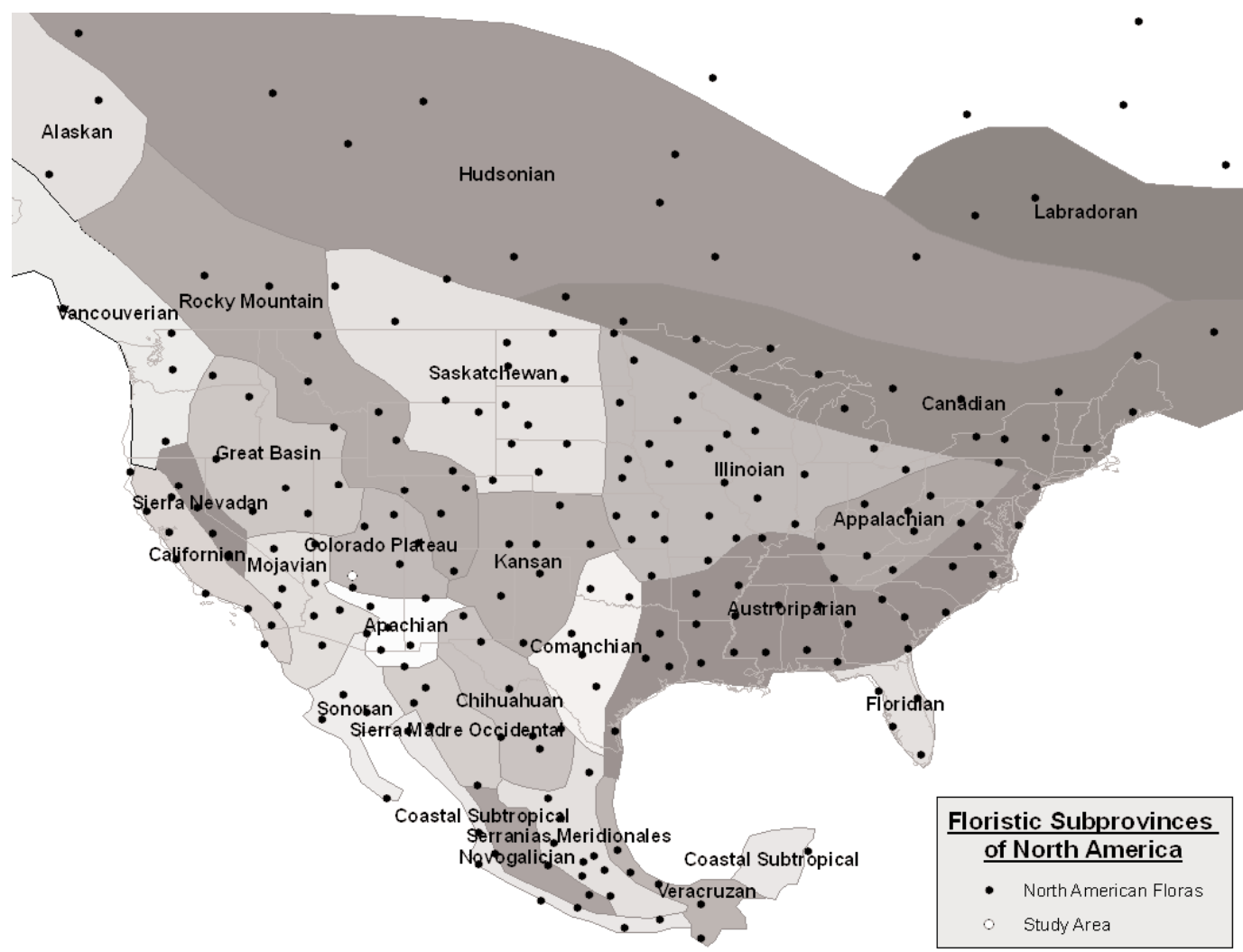

Fig. 1. Floristic subprovinces of North America and the 245 local floras used to delimit them (McLaughlin 2007).

Opuntia macrorhiza Engelm., Ptelea trifoliata L., Andropogon gerardii Vitman, Elymus canadensis L., Monarda fistulosa L., Panicum virgatum L., Schedonnardus paniculatus [Nutt.] Trel., Schizachyrium scoparium [Michx.] Nash, Sorghastrum nutans [L.] Nash, and Zinnia grandiflora Nutt.) reach their western distributional limits on the Colorado Plateau.

The western United States, and particularly the Southwest, has a relatively high degree of floristic differentiation compared to the eastern United States (McLaughlin 2007; Fig. 1). Different climatic regimes and migrational barriers imposed by the physical geography of the region often promote floristic diversity. The $\mathrm{SFVF}$ is situated at the southern edge of the Colorado Plateau and lies at a unique physiographic crossroads. The 4 major North American deserts border the Colorado Plateau on 3 sides, and the Rocky Mountains confine the region on the northeast. Drastically distinct physiographic influences from the Great Basin, Great Plains, and Rocky Mountain provinces converge on the Colorado Plateau (Bailey et al. 1994, Bailey 1998) to create an area with an eclectic, yet not entirely understood, floristic composition.

Pinyon-juniper (PJ) woodlands cover more than 24 million ha in the southwestern United States (Tidwell 1987) and represent one of the most expansive vegetation types in the region (Brown 1994). These woodlands are the most extensive vegetation type in the Colorado Plateau Semidesert Province (Bailey et al. 1994) and occupy more area in the Intermountain Region than all other forest types combined (Cronquist et al. 1972). Due to the extensive coverage of PJ woodlands on the Colorado Plateau, and in the Southwest and Intermountain regions, the lower SFVF provides an ideal arena in which to test the hypothesis that the area shares strong affinities with the adjacent Colorado Plateau and Apachian floristic subprovinces as well as with the Great Basin ecophysiographic province (due to expansive coverage of PJ woodlands 
in both regions). A phytogeographical analysis using a geographic information system (GIS) will help to elucidate the eclectic floristic influences of the area and provide a spatially explicit model of floristic similarity.

\section{Local Floristic Diversity}

In addition to its diverse ecophysiographic influences, the SFVF also encompasses a large altitudinal range. Elevations range from higher than $3800 \mathrm{~m}$ at the top of the San Francisco Peaks to $1300 \mathrm{~m}$ at the lower reaches of the volcanic field. Within a $10-\mathrm{km}$ radius, biotic communities range from alpine tundra to desert grasslands (Brown and Lowe 1980, Brown 1994). Existing data supply complete vascular plant checklists for each biotic community of the SFVF (including alpine tundra, spruce-fir forests, mixed conifer forests, ponderosa pine forests, PJ woodlands, and desert grasslands); thus the area provides an interesting opportunity to examine local-scale floristic patterns among major biotic communities of the Southwest. Just as examining PJ woodlands of the SFVF can improve understanding of the regional biogeography, examining local floristic patterns can illuminate finer-scale floristic patterns throughout PJ woodlands of the Southwest and Intermountain Region.

The structure of PJ woodlands is among the simplest of any major vegetation type in the Southwest (Brown 1994), and this fact, perhaps falsely, suggests that it is also one of the floristically simplest vegetation types in the region. The PJ woodlands of the SFVF lie just below the middle of a landscape-wide elevational continuum. Along elevation gradients, ecosystems of middle elevations often show the highest levels of species diversity (Colwell and Lees 2000, Lomolino 2001, Colwell et al. 2004), as species from both higher and lower biotic communities can intermix at intermediate elevations. Several elevation-gradient analyses of species richness (e.g., Lieberman et al. 1996, Grytnes and Vetaas 2002), including several local Arizona studies (Whittaker and Niering 1965, 1975, Fernandes 1992), corroborate these findings. In terms of the landscape-wide matrix, the PJ woodlands of the SFVF fall just below this "mid-domain" species-richness peak and are expected to host a moderately rich flora composed of a mix of species found in both higher and lower biotic communities. An analysis of species occurrences between 6 adjacent biotic communities in the SFVF will help to illuminate species-richness and floristic-differentiation patterns across a 2500-m elevation gradient in northern Arizona and perhaps highlight patterns applicable to other PJ woodlands on the Colorado Plateau and throughout the western United States.

\section{METHODS}

\section{Study Area}

The San Francisco Volcanic Field lies near the southern edge of the Colorado Plateau in north central Arizona and south central Coconino County. The lower SFVF, and synonymously the study area, is defined as the contiguous portion of the greater SFVF that is dominated by Pinus edulis Engelm. and Juniperus monosperma (Engelm.) Sarg. The study area is elevationally bound by Petran montane coniferous forests above and by grasslands below. It lies between $35^{\circ} 10^{\prime} 47^{\prime \prime}$ and $35^{\circ} 41^{\prime} 30^{\prime \prime}$ latitude and between $-111^{\circ} 21^{\prime} 3^{\prime \prime}$ and $-112^{\circ} 10^{\prime} 12^{\prime \prime}$ longitude, is irregularly horseshoe shaped and essentially envelops the higher-elevation San Francisco Peaks on the north, east, and west sides. The study area extends about $75 \mathrm{~km}$ east-west and between 5 and 27 kilometers north-south; it encompasses approximately $1134 \mathrm{~km}^{2}$. Elevations range from 1700 to $2400 \mathrm{~m}$; however, $84 \%$ of the study area occurs between 1829 and 2134 $\mathrm{m}$. Approximately 70 widely spaced cinder cones dot the otherwise flat plateau of the lower SFVF. The study area lacks stream/river systems and bodies of water, and perennial water is essentially absent. Igneous soils and rocks ubiquitously dominate the local landscape. Basaltic rocks from the Holocene to Middle Pliocene cover $80 \%$ of the study area, while additional igneous deposits (9\%) and Permian sedimentary deposits (11\%) compose the additional surficial geology (Richard et al. 2000).

\section{Regional Floristic Affinities}

Floristic affinities of the lower San Francisco Volcanic Field were determined by measuring the pairwise similarity of the flora (Christie 2008) with 245 other North American floristic checklists. Only native vascular plants were used in the analysis. The floras used in the analysis occur fairly uniformly throughout Mexico and the United States and 
sporadically throughout Canada (Fig. 1). Species-occurrence data follow the checklists used by McLaughlin (2007) in his extensive work on North American plant geography. The Otsuka similarity index (OI) was used as the test statistic and was calculated as

$$
\mathrm{OI}=C_{i j} /\left(A_{i} \times B_{j}\right)^{0.5}
$$

where $A_{i}=$ the number of species in flora $i, B_{j}$ $=$ the number of species in flora $j$, and $C_{i j}=$ the number of species shared in floras $i$ and $j$. The Otsuka similarity index is commonly used in floristic analyses as it compares occurrence rather than frequency or abundance, is appropriate for comparing differently sized entities, and is mathematically admissible (McLaughlin 1986). Otsuka similarity coefficients range from 0 to 1 ; a value of 0 represents mutual exclusivity between 2 floras, while a value of 1 represents complete overlap between 2 floras. These values approximate but do not exactly equal percent similarity, as input floras are invariably of different sizes.

An Otsuka similarity coefficient was determined for each of 245 local North American floras (Fig. 1), representing the affinity between the PJ woodlands of the SFVF and the respective local flora. An interpolated surface of Otsuka similarity values was then created in ArcGIS 9.0 via ordinary kriging to spatially depict geographic patterns of floristic affinity. A spherical semivariogram model and a variable search radius were used in the analysis.

A secondary geographic analysis was conducted to determine the floristic affinities of (1) the most common plants, (2) the woody plants, and (3) the grasses of the lower SFVF. As in the overall analysis, only native vascular taxa were used. Ordinary kriging was conducted in ArcGIS 9.0 using a spherical semivariogram model and a variable search radius to create a probability surface of species presence based on overall species occurrence within 245 North American floras (McLaughlin 2007). An individual surface was created for each species, and then a cumulative probability surface was derived for each life-form via summation of the individual interpolated surfaces. The most common plants were those subjectively determined to be abundant or frequent within the study area, following the abundance scale of Palmer et al. (1995). Woody plants included all trees and shrubs, while grasses included the entire native Poaceae of the lower SFVF (Christie 2008). The common species of the SFVF were chosen for the analysis because they are locally dominant and compose the majority of plant biomass; the woody plants were chosen because they are long lived and fairly resistant to short-term climatic fluctuations; and the grasses were chosen due to their ecological importance in semiarid systems.

Kriging is a geostatistical analysis technique that predicts unsampled values based on relationships to sampled points (Childs 2004). Kriging inherently assumes spatial dependence in the sample data; that is to say, the values of adjacent points (i.e., the floristic similarity of 2 adjacent areas) will be more similar than the values of distant points (Oliver and Webster 1990). Kriging has great promise in analyzing floristic data at several scales and is especially conducive to phytogeographical inquiries (Palmer 1995) because the technique addresses the inherent spatial autocorrelation in floristic data and produces spatially explicit results. The technique has been used successfully to predict vegetation distributions on scales from several meters to several kilometers (e.g., Miller and Franklin 2002, Valley et al. 2005), as well as in continental-scale floristic analyses (McLaughlin 2007). Other statistical and geostatistical interpolation techniques are inadequate for spatially autocorrelated data, which inherently violate many assumptions associated with parametric statistics (Lichstein et al. 2002). Maps created via kriging provide readily accessible information, allow for overlap of pertinent data layers, and provide a simple and informative method to present floristic data (Ozenda and Boral 2000).

\section{Local Floristic Diversity}

Alpine tundra, spruce-fir, mixed conifer, and ponderosa pine life-zone checklists from the higher-elevation SFVF (Moir 2006); a pinyon-juniper woodlands checklist (Christie 2008); and a cumulative desert grasslands checklist were used to assess the floristic diversity and distinctiveness of each of the biotic communities of the SFVF. These species checklists represent thorough inventories for each of the respective life zones. Moir's (2006) checklists are based on complete herbarium searches (from an extensively collected area) of the 


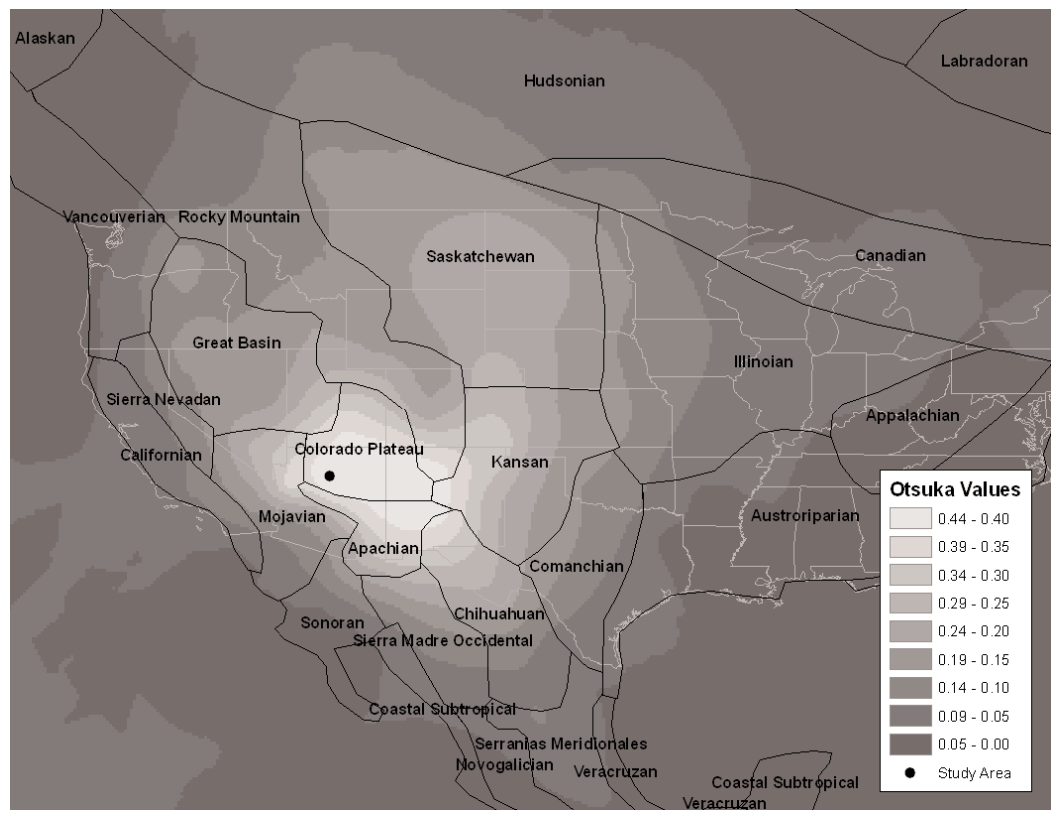

Fig. 2. Interpolated surface of Otsuka similarity values (a graphical representation of the floristic affinities of the lower San Fransisco Volcanic Field). Floristic subprovinces of North America follow McLaughlin (2007).

TABLE 1. Average affinity of the lower San Francisco Volcanic Field to North American floristic subprovinces.

\begin{tabular}{lcc}
\hline Floristic subprovince & $\begin{array}{c}\text { Mean Otsuka } \\
\text { similarity value }\end{array}$ & $\begin{array}{c}\text { Standard } \\
\text { deviation }\end{array}$ \\
\hline Apachian & 0.385 & 0.086 \\
Colorado Plateau & 0.376 & 0.076 \\
Kansan & 0.243 & 0.073 \\
Great Basin & 0.211 & 0.022 \\
Saskatchewan & 0.206 & 0.048 \\
Mojavian & 0.168 & 0.074 \\
Chihuahuan & 0.142 & 0.106 \\
Rocky Mountain & 0.136 & 0.033 \\
\hline
\end{tabular}

Deaver Herbarium (ASC) and the Museum of Northern Arizona (MNA) and on selective digital searches of the ASU and ARIZ herbaria via Southwestern Environmental Information Network's query tools (SEINet 2005). The pinyon-juniper checklist was created via a thorough floristic inventory (Christie 2008). The Wupatki National Monument checklist, which represents the desert grasslands of the SFVF, is based upon a complete floristic inventory, various updates, and species additions from a vegetation mapping project (Rominger 1976, NPS 1993, McLaughlin 1998, Hansen et al. 2004). A list of species that occur within each life zone as well as the number of species exclusive to each lifezone were determined from these lists.

\section{REsults}

\section{Regional Floristic Affinities}

The flora of the lower SFVF shows the highest affinities to the adjacent Apachian and Colorado Plateau floristic subprovinces as expected, but it also shows high affinities to the Kansan, Great Basin, and Saskatchewan floristic subprovinces (Table 1). Data suggest that mid-elevation woodlands of the Colorado Plateau share floristic affinities with the Great Plains that are as strong as or stronger than those shared with the Great Basin. Figure 2 depicts an interpolated surface of Otsuka similarity values and provides a geographic representation of the floristic affinities of the study area. Map contours of relatively high Otsuka values extend well into the Great Plains province; however, they are restricted to the southern edge of the Great Basin province (Fig. 2). Based on Otsuka similarity values, of the 25 floras which are most similar to the lower SFVF, only 1 occurs in the Great Basin floristic subprovince (Stansbury Mountains, $\mathrm{NV}$, OI $=0.248)$, while 6 of 25 occur in the 
Kansan and Saskatchewan floristic subprovinces of the Great Plains (Mesa de Maya region, $\mathrm{CO}$, OI $=0.383$; Pawnee National Grassland, $\mathrm{CO}, \mathrm{OI}=0.304$; Badlands National Park, SD, $\mathrm{OI}=0.267$; Melrose Air Force Range, NM, $\mathrm{OI}=0.248$; Billings County, ND, OI =0.247; and Butte County, SD, OI $=0.244$; see McLaughlin 2007 for flora references).

While the Colorado Plateau and Great Basin share expansive tracts of PJ woodlands, the floristic composition of these woodlands varies appreciably across their range. Regional floristic influences, as opposed to woodland structure, seem to primarily drive the composition of local plant species. The 5 North American floras that are most floristically similar to the lower SFVF (Datil Mountains, NM, $\mathrm{OI}=0.505$; Greater Sedona, $\mathrm{AZ}, \mathrm{OI}=0.488$; Canyon de Chelly, AZ, OI $=0.468$; Bandelier National Monument, NM, OI $=0.44$; and Hualapai Mountain Park, AZ, OI = 0.435) also encompass varying amounts of PJ woodlands; however, all of these floras occur in the Apachian and Colorado Plateau floristic subprovinces and lie on average only $282 \mathrm{~km}$ from the SFVF. The Southwest harbors a high degree of regional endemism, and southwestern species are often narrowly restricted geographically (McLaughlin 1986). Although PJ woodlands make up a vast portion of the Southwest's landscape and although they endure fairly similar climatic conditions across their range (Brown 1994), the floras of PJ woodlands from disparate areas certainly appear distinctive as a result of biogeographical influences, as evidenced by the relative lack of similarity between PJ-dominated portions of the Colorado Plateau and PJ-dominated portions of the Great Basin.

In addition to the Otsuka analysis, cumulative probability surfaces for the occurrence of important life-forms were created to potentially clarify floristic affinity patterns of the Colorado Plateau's mid-elevation woodlands. These surfaces depict the probability that a plant (i.e., a common plant, a woody plant, or a grass) from the lower SFVF also occurs elsewhere. The probability surfaces for both the common species and the woody species are centered around the Colorado Plateau and Apachian floristic subprovinces (and essentially follow the extent of these subprovinces shown in Fig. 1) and therefore are not depicted here. However, the cumulative probability surfaces for grass species of the lower SFVF show a distinct affinity towards Kansan and Saskatchewan floristic influences from the Great Plains region (Fig. 3) and essentially follow the largest Otsuka contour value (Fig. 2). This similarity of patterns shown in Fig. 2 and Fig. 3 suggests that the grasses, as opposed to common perennials, trees, or shrubs, strongly affect the floristic similarity between the Colorado Plateau and the Great Plains.

Two major factors, (1) similar climatic conditions and associated physiological tolerances and (2) evolutionary history, seem to influence 2 separate groups of grass species in the lower SFVF. The first group consists of those species typically found in the Great Plains region, such as Bouteloua curtipendula (Michx.) Torr., Hesperostipa comata (Trin. \& Rupr.) Barkworth, Panicum virgatum L., Schizachyrium scoparium (Michx.) Nash, and Sorghastrum nutans (L.) Nash. These grasses likely thrive on the southern Colorado Plateau and in the Great Plains because both regions share similar annual precipitation totals, summer precipitation patterns, and minimum July temperatures (SCAS 2006), factors known to affect the physiological amplitude of plant species (Iversen 1954, Birks 1981). The second group of grass species (including Aristida arizonica Vasey, Bouteloua aristidoides [Kunth] Griseb., Lycurus setosus [Nutt.] C.G. Reeder, Muhlenbergia torreyi [Kunth] Hitchc. ex Bush, and Panicum bulbosum Kunth) shows affinity towards Madrean and Chihuahuan floristic elements from southern New Mexico and northern Mexico. This may be attributable to the evolutionary history of the locally wellrepresented Chloridoideae, as plants with $\mathrm{C}_{4}$ photosynthesis are well represented in arid and semiarid environments (Judd et al. 2002). Likewise, the locally well-represented Aristida L. thrives in open, semiarid habitats worldwide (Flora of North America Editorial Committee 1993+).

\section{Local Floristic Diversity}

The hypothesis that PJ woodlands host a moderately species-rich flora in comparison to other biotic communities of the SFVF is accepted; however, the hypothesis that the local PJ flora is composed of an indistinctive mix of species from higher and lower biotic communities is clearly rejected. The PJ woodlands of the SFVF host more restricted species 


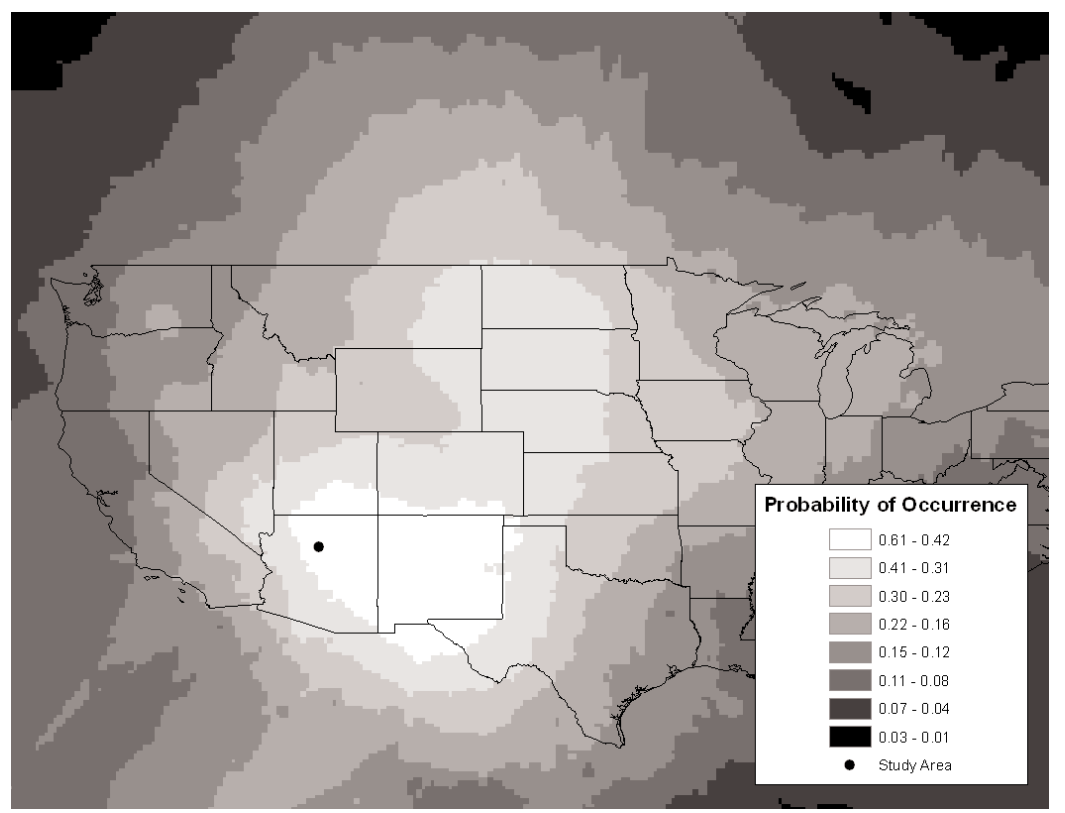

Fig. 3. Cumulative probability that a grass species from the lower San Francisco Volcanic Field occurs elsewhere.

TABLE 2. Landscape-wide floristic diversity and distinctiveness within the San Francisco Volcanic Field (the floristic distinctiveness of desert grasslands could not be determined without an adjacent biotic community, which is absent in the San Francisco Volcanic Field).

\begin{tabular}{lcccc}
\hline Life zone & Species & $\begin{array}{c}\text { Flora } \\
\text { uniqueness }\end{array}$ & $\begin{array}{c}\text { Unique } \\
\text { taxa }\end{array}$ & $\begin{array}{c}\text { Elevation } \\
\text { range }(\mathrm{m})\end{array}$ \\
\hline Desert grasslands & 364 & - & - & $1311-1737$ \\
PJ woodlands & 487 & $28 \%$ & 137 & $1737-2073$ \\
Ponderosa pine forest & 581 & $24 \%$ & 139 & $2073-2530$ \\
Mixed conifer forest & 419 & $17 \%$ & 71 & $2530-2835$ \\
Spruce-fir forest & 285 & $14 \%$ & 40 & $2835-3536$ \\
Alpine tundra & 94 & $12 \%$ & 11 & $3536-3841$ \\
\hline
\end{tabular}

than any other single biotic community of the SFVF. Twenty-eight percent (137 taxa) of the PJ flora is restricted to this single life zone. Data highlight an inverse relationship between elevation and floristic distinctiveness (Table 2). In the SFVF, as elevation increases, the distinctiveness of the flora decreases.

\section{Discussion}

\section{Regional Floristic Affinities}

The geographic regions with which the lower San Francisco Volcanic Field shares the highest floristic affinities are fairly similar ecophysiographically. The areas encompass tropi$\mathrm{cal} /$ subtropical steppe or temperate steppe, and they have similar climates (Bailey et al.
1994, Bailey 1998). The southwestern regional landscape also imposes significant physiological migration barriers. Figure 2 shows the area in which the floristic assemblage of the lower SFVF is the best developed. To the south below the Mogollon rim and to the southwest of this zone, elevation drops precipitously and Sonoran and Mojavean elements predominate. A similar pattern manifests itself to the southeast as lower elevations, warmer temperatures, and less precipitation favor Chihuahuan elements. To the east, lower elevations, additional precipitation, and cooler temperatures favor Great Plains grasslands. Considerable physical barriers imposed by massive canyon networks, as well as autumn and spring precipitation regimes as opposed to a summer precipitation 
regime, influence the vegetation to the north. To the northeast, the Rocky Mountains harbor a colder, wetter, higher-elevation flora more reminiscent of the Pleistocene. The flora of the lower SFVF is essentially bound by these ecophysiographic constraints.

The southwestern United States also harbors a very high level of local endemism, and species are narrowly restricted geographically and presumably of recent origin. Over one-fifth of southwestern species are regionally endemic, and over one-fourth of the dicotyledons are restricted to the region (McLaughlin 1986). In an analysis of 50 welldistributed local floras from the southwestern United States, McLaughlin (1986) found that a given species occurred in only 4 out of 50 floras on average and that almost twothirds of the species occurred in 3 or fewer floras. Fewer than $2 \%$ of the taxa are widely distributed throughout the region (McLaughlin 1986). Regardless of ecological tolerances, many Southwestern taxa simply may not have had time since Holocene speciation events to migrate to the extremes of their physiological limits and thus still display fairly limited distributions. PJ woodlands of the southern Colorado Plateau are most similar to other Apachian and Colorado Plateau floristic elements, predominantly because they are adjacent and share fairly similar climatic regimes.

\section{Local Floristic Diversity}

Pinyon-juniper woodlands of the San Francisco Volcanic Field host a moderately speciesrich flora, while ponderosa pine forests host the most species-rich flora among local biotic communities. These findings support the "middomain" theory, as species richness decreases as elevation either increases or decreases from the "mid-domain" ponderosa pine life zone (Table 2). Despite their uniform forest structure, PJ woodlands do, in fact, host a moderately rich flora; however, the flora is not composed only of species from higher and lower biotic communities as the "mid-domain" theory might suggest. PJ woodlands of the SFVF host the most distinctive flora among local biotic communities and highlight an inverse correlation between elevation and floristic discreteness. This study lacked the data to calculate the floristic distinctiveness for lower elevation biomes; however, this pattern may persist into the lower desert life zones and should certainly be tested in other areas.

Data from this study raise a fascinating question: why is the assemblage of plant species growing at lower elevations more distinctive than the assemblage growing at higher elevations on the same mountain slope? Rapoport's latitudinal rule contends that as latitude increases so do the latitudinal ranges of species (Taylor and Gaines 1999). In other words, equatorial species are typically more latitudinally restricted, while temperate and circumpolar species are more wide ranging. Climatic extremes determine the physiological and ecological scope of species (Iversen 1954, Birks 1981), and since altitudinal gradients effectively mimic climatic variation across latitudinal gradients (Merriam 1894), Stevens (1992) cogently suggests that Rapoport's latitudinal rule can be extended to altitudinal gradients. He suggests that low-elevation species are relatively restricted elevationally, whereas high-elevation species are more wide ranging.

Stevens (1992) proposes that Rapoport's latitudinal rule applies because the degree of climatic heterogeneity increases with increasing latitude. Equatorial or tropical species experience such a narrow scope of climatic variability and seasonal change that they face no evolutionary consequence for possessing narrow physiological tolerances; but high-latitude species must endure a drastically variable climate to simply survive and reproduce (Stevens 1992). Since the variation of climatic conditions increases with both latitude and altitude, higher-latitude and higher-altitude species are anticipated to have broader physiological tolerances and geographic distributions. Findings from both plant and animal studies support the extension of Rapoport's latitudinal rule to altitudinal gradients (Stevens 1992). Janzen (1967) lends support to the argument by proposing that infrequent contact with environmental change promotes an increased sensitivity to climatic variations. It follows that for species which typically encounter a more uniform climatic regime (those at lower latitudes or lower altitudes), smaller changes in environmental conditions act as relatively large dispersal barriers (Janzen 1967). Since the PJ woodlands of the SFVF (and many PJ woodlands throughout the West) often occur at the bases of mountains and experience less climatic heterogeneity than higher-elevation 
ecosystems, it follows (if the argument above is correct) that they should harbor a more unusual, geographically restricted flora.

These findings suggest far-reaching ramifications toward an understanding of the floristics of PJ woodlands throughout the West. Pinyon-juniper communities cover expansive, middle-elevation tracts throughout the West, and they may, in fact, be acting as conservation-worthy repositories for distinctive plant species of the Colorado Plateau, the Southwest, and the Intermountain Region.

\section{Conclusions}

This study illustrates that PJ woodlands on the southern Colorado Plateau have strong affinities with adjacent floristic elements but also show strong floristic affinities with the Great Plains. Data suggest that mid-elevation PJ woodlands of the Colorado Plateau perhaps share stronger floristic similarities with the Great Plains than they share with the Great Basin. Findings propose that within mountainous regions of the western United States, PJ woodlands can host unusual and conservationworthy floras. This study also highlights an inverse correlation between elevation and floristic differentiation, a relationship that should certainly be tested in other regions and ecosystems and with other organisms.

\section{ACKNOWLEDGMENTS}

I thank my major advisor, Tina Ayers, for her exceptional guidance throughout this project. The staff of the Deaver Herbarium, H. David Hammond, Daniela Roth, Kristin Henningsen, and Mar-Elise Hill, provided invaluable daily support and assistance. Will Moir's tireless work on Vascular Plants of the San Francisco Peaks Area provided data for the comparative aspects of this project. I owe immense gratitude to Steven McLaughlin; he went well out of his way to provide me with a customized query of his extensive floristic database. Without his effort and previous research on floristics of the Southwest, the phytogeographical analysis in this study would not have been possible.

\section{Literature Cited}

BAILEY, R.G. 1998. Ecoregions map of North America. USDA Forest Service Miscellaneous Publication No. 1548.
Bailey, R.G., P.E. Avers, T. King, and W.H. McNab. 1994. Map of the ecoregions and subregions of the United States. W.H. McNab and R.G. Bailey, compilers and editors. USDA Forest Service, Washington, DC. 1:7,500,000; with supplementary table of map unit descriptions.

BirKs, H.J.B. 1981. The use of pollen analysis in the reconstruction of past climates: a review. Pages 111-138 in T.M.L. Wigley, M.J. Ingram, and G. Farmer, editors, Climate and history: studies in past climates and their impact on man. Cambridge University Press, Cambridge, U.K.

BRown, D.E. 1994. Biotic communities: southwestern United States and northwestern Mexico. University of Utah Press, Salt Lake City.

BRown, D.E., AND C.H. LOWE. 1980. Biotic communities of the Southwest. USDA Forest Service General Technical Report RM-78. Map at 1:1,000,000 scale.

ChILDS, C. 2004. Interpolating surfaces in ArcGIS Spatial Analyst. ArcUser (July-September):32-35.

Christie, K. 2008. Vascular flora and floristic analysis of the lower San Francisco Volcanic Field, Coconino County, Arizona. Madroño 55:1-14.

Colwell, R.K., AND D.C. LeEs. 2000. The mid-domain effect: geometric constraints on the geography of species richness. Trends in Ecology and Evolution 15:70-76.

Colwell, R.K., C. Rahbek, and N.J. Gotelli. 2004. The mid-domain effect and species richness patterns: what have we learned so far? American Naturalist 163:1-23.

Croneuist, A., A. Holmgren, N. Holmgren, and J. REVEAL. 1972. Intermountain flora: vascular plants of the Intermountain West, USA. Volume 1. Hafner Publishing Company, New York.

Fernandes, G.A. 1992. A gradient analysis of plant forms from northern Arizona. Journal of the ArizonaNevada Academy of Science 24-25:21-30.

Flora of North America Editorial Committee. 1993+. Flora of North America north of Mexico. Oxford University Press, New York and Oxford.

GooD, R. 1974. The geography of the flowering plants. 4th edition. Longman, London.

Grytnes, J.A., And O.R. VetaAs. 2002. Species richness and altitude, a comparison between simulation models and interpolated plant species richness along the Himalayan altitudinal gradient, Nepal. American Naturalist 159:294-304.

Hansen, M., K. Coles, D. Thomas, M. Cogan, J. Reid, J. VON LOH, AND K. Shulz. 2004. USGS-NPS National Vegetation Mapping Program: Wupatki National Monument. Final Report, U.S. Geological Survey, Southwest Biological Center, Flagstaff, AZ.

Iversen, J. 1954. The Late-Glacial flora of Denmark and its relation to climate and soil. Danmarks Geologiske Undersøgelse 2:87-119.

JANZEN, D.H. 1967. Why mountain passes are higher in the tropics? American Naturalist 101:233-249.

Judd, W.S., C.S. Campbell, E.A. Kellogg, P.F. Stevens, And M.J. Donoghue. 2002. Plant systematics: a phylogenetic approach. 2nd edition. Sinauer Associates, Sunderland, MA.

Lichstein, J.W., T.R. Simons, S.A. Shriner, and K.E. FRANZREB. 2002. Spatial autocorrelation and autoregressive models in ecology. Ecological Monographs 72:445-463.

Lieberman, D., M. Lieberman, R. Peralta, and G.S. HARTSHORN. 1996. Tropical forest structure and 
composition on a large-scale altitudinal gradient in Costa Rica. Journal of Ecology 84:137-152.

Lomolino, M.V. 2001. Elevation gradients of speciesdensity: historical and prospective views. Global Ecology and Biogeography 10:3-13.

MCLaughlin, S.P. 1986. Floristic analysis of the southwestern United States. Great Basin Naturalist 46:46-65. 1989. Natural floristic areas of the western United States. Journal of Biogeography 16:239-248. . 1992. Are floristic areas hierarchically arranged? Journal of Biogeography 19:21-32.

1994. Floristic plant geography: the classification of floristic areas and floristic elements. Progress in Physical Geography 18:185-208.

1998. Plants of Arizona national parks, monuments, and historic sites. I. Wupatki National Monument. Plant Press 22(2):6-10.

2007. Tundra to tropics: the floristic plant geography of North America. Sida, Botanical Miscellany 30:1-58.

Merriam, C.H. 1894. Laws of temperature control of the geographic distribution of terrestrial animals and plants. National Geographic 6:229-238.

MilLer, J., AND J. FrankLIn. 2002. Modeling the distribution of four vegetation alliances using generalized linear models and classification trees with spatial dependence. Ecological Modeling 157:227-247.

MoIr, W. 2006. Vascular plants of the San Francisco Peaks area [unpublished checklist]. Deaver Herbarium, Northern Arizona University, Flagstaff.

[NPS] National Park Service. 1993. Species in parks: flora and fauna database online query system. Information Center for the Environment. University of California Davis, Davis. Available from: http://ice .ucdavis.edu/nps/sbypark.html.

Oliver, M.A., AND R. Webster. 1990. Kriging: a method of interpolation for GIS. International Journal of Geographical Information Systems 4:313-332.

Ozenda, P., AND J. Borel. 2000. An ecological map of Europe: why and how? Life Sciences 323:983-994.

Palmer, M.W. 1995. How should one count species? Natural Areas Journal 15:124-135.

Palmer, M.W., G.L. Wade, and P. Neal. 1995. Standards for the writing of floras. BioScience 45:339-345.

Richard, S.M., S.J. Reynolds, J.E. SPEncer, and P.A. Pearthree. 2000. Geologic map of Arizona (a revision of AZGS MAp 26). Arizona Geologic Survey, Tucson.
Rominger, J.M. 1976. A checklist of the vascular plants of Wupatki and Sunset Crater National Monuments. Unpublished report. Northern Arizona University, Flagstaff.

[SEINet] Southwest EnVIronmental Information NeTwork. 2005. Arizona biological data network. Arizona State University Center of Environmental Studies, Phoenix AZ. Available from: http://seinet. asu.edu/.

[SCaS] Spatial Climate Analysis Service. 2006. Maps (precipitation: annual climatology 1971-2000, and minimum temperature: July climatology 1971-2000) [created 1 February 2006]. Oregon State University, Corvallis. Available from: http://www.ocs.oregonstate. edu/prism/.

Stevens, G.C. 1992. The elevational gradient in altitudinal range: an extension of Rapoport's latitudinal rule to altitude. American Naturalist 140:893-911.

Sтотт, P. 1981. Historical plant geography. George Allen and Unwin, London.

TakHTajan, A. 1986. Floristic regions of the world. University of California Press, Berkeley.

TAYLOR, P.H., AND S.D. GaINES. 1999. Can Rapoport's rule be rescued? Modeling causes of the latitudinal gradient in species richness. Ecology 80:2474-2482.

TidwelL, D.P. 1987. Pinyon-juniper woodlands: times have changed but do we know it? Pages 5-8 in Proceedings of the Pinyon-Juniper Conference. USDA Forest Service General Technical Report INT-125.

Valley, R.D., M.T. Drake, and C.S. Anderson. 2005. Evaluation of alternative interpolation techniques for the mapping of remotely-sensed submersed vegetation abundance. Aquatic Botany 18:13-25.

Westoby, M., AND I. WRight. 2006. Land-plant ecology on the basis of functional traits. Trends in Ecology and Evolution 21:261-268

WhitTaker, R.H., and W.A. Niering. 1965. Vegetation of the Santa Catalina Mountains, Arizona: a gradient analysis of the south slope. Ecology 46:429-452.

. 1975. Vegetation of the Santa Catalina Mountains, Arizona. Biomass production, and diversity along the elevational gradient. Ecology 56:771-790.

Received 13 March 2007 Accepted 24 September 2008 